\title{
Corn Tassel: A New Source of Phytochemicals and Antioxidant Potential for Value-Added Product Development in the Agro-Industry
}

\author{
Prakasit Duangpapeng ${ }^{1}$, Danupol Ketthaisong ${ }^{2,3}$, Khomsorn Lomthaisong ${ }^{4}$, Kamol Lertrat ${ }^{3}$, \\ Marvin Paul Scott 5 (D) and Bhalang Suriharn $1,3, * \mathbb{D}$ \\ 1 Department of Agronomy, Khon Kaen University, Khon Kaen 40002, Thailand; prakasitkku@gmail.com \\ 2 Department of Horticulture, Khon Kaen University, Khon Kaen 40002, Thailand; danuket@kku.ac.th \\ 3 Plant Breeding Research Center for Sustainable Agriculture, Khon Kaen University, \\ Khon Kaen 40002, Thailand; kamol9@gmail.com \\ 4 Department of Biochemistry, Khon Kaen University, Khon Kaen 40002, Thailand; kholom@kku.ac.th \\ 5 USDA-ARS Corn Insects and Crop Genetics Research Unit, Iowa State University, Ames, IA 50011, USA; \\ paul.scott@ars.usda.gov \\ * Correspondence: bsuriharn@gmail.com; Tel.: +66-43-202-696
}

Received: 26 September 2018; Accepted: 29 October 2018; Published: 31 October 2018

\begin{abstract}
Corn tassel is a byproduct from hybrid corn seed production. It is also a new source of phytochemicals, including compounds with antioxidant activity. The aim of this study was to evaluate the phytochemical content and antioxidant potential of different corn tassel development stages. A $4 \times 8$ factorial experiment consisting of four tassel development stages and eight commercial corn varieties was carried out with a randomized complete block design with three replications. Data were collected for tassel weight, concentration and yield of total phenolics, total anthocyanin concentration, total carotenoid concentration, and antioxidant activity, as determined by the 2,2-diphenyl-1-picrylhydrazyl( $\left.\mathrm{DPPH}^{\bullet}\right)$ radical scavenging assay and Trolox equivalent antioxidant capacity(TEAC) assays. Corn varieties and tassel developmental stages showed significant variations $(p \leq 0.01)$ in all parameters. $P 4546$ presented the best variety for the total phenolic content (15.8 mg GAE/g DW sample), whereas Hibrix3 had the highest phenolic yield (6.78 kg GAE/ha). KGW1, a purple waxy variety, had the highest anthocyanin content (1528.0 $\mu \mathrm{g}$ CGE/g DW sample), anthocyanin yield (753.0 g CGE/ha), carotenoid content $(74.9 \mu \mathrm{g} / \mathrm{g}$ DW sample), and carotenoid yield (53.7 g/ha). P4546 had the highest antioxidant activity: 92.4\% for DPPH ${ }^{\bullet}$ and $76.1 \mu \mathrm{mol} \mathrm{TE} / \mathrm{g}$ DW sample for the TEAC assay, respectively. The most appropriate time for tassel harvest to ensure the production of phytochemicals with high antioxidant activity should be from the 1st day of pollen shed until 50\% of pollen shed. Phytochemicals and antioxidants that are extracted from corn tassel can be used as a functional food supplement, as natural pharmaceuticals, and in cosmetic products.
\end{abstract}

Keywords: Zea may L.; bioactive compound; floral corn; byproducts; beepollen

\section{Introduction}

Corn (Zea may L.) is an important cereal crop worldwide. Corn kernels are used in cooking as a vegetable and a source of starch and bioactive compounds. Corn kernels are also used as a raw material for food products, animal feed, and bio-ethanol production. Other byprodcuts from corn production, such as corn tassels and corn cobs, are also rich in the bioactive compounds. Moreover, more downstream research is required to better utilize corn byproducts. This includes the development of reliable and effective extraction methods to recover phytochemicals, as well as determination of the components of phytochemicals and their benefits in treating specific illness. 
Corn silk is rich in flavonoids, anthocyanins [1,2] and phenolic compounds [1,3]. Corn husk has high contents of anthocyanins [2,4], phenolic compounds [3,4], flavonoids [3], and anthocyanins [4]. Corn pollen has a high content of phenolic compounds [2]. These phytochemicals are natural pigments in plant parts, and they function as antioxidants that are beneficial to health. Their health benefits include anti-apoptosis, anti-aging, anti-carcinogen, anti-inflammation, anti-atherosclerosis, and cardiovascular protection effects [5].

Corn tassel on the top of the corn plant produces pollens that are carried by the wind to pollinate female flowers called silk. On average, a tassel can produces 25 million pollen grains [6]. The pollen grains are viable for 60-240 min after shedding and can move further than $300 \mathrm{~m}$ [7]. An ear of corn typically produces no fewer than 1000 filled kernels and, therefore, each tassel produces excess pollen to pollinate the ear. In hybrid seed production, a male row is sufficient to pollinate $2-3$ female rows, and ratios of 1:4 or 1:6 male:female rows do not affect seed setting [8]. In order to prevent self pollination of the female plant, the female rows are detasselled prior to pollen shed and the tassel is considered to be a waste product.

Pollen has high potential for the development of health food products. Sweet corn pollen is an excellent source of antioxidants and is high in nutrients such as sugar, protein, and oils [9]. Bee pollen is commercially available because it is an excellent source of carbohydrates, protein, lipids, vitamins, carotenoids, and bioactive compounds [10]. Bee pollen is used for cosmetics, dietary supplements, and functional foods. However, the production of bee pollen is low, time consuming, and not practical for large-scale production.

Moreover, previous reports suggested that corn tassel extract has antioxidant capacity [11] and a high ability to inhibit the proliferation of MGC80-3 gastric cancer cells [12]. Tasselin A extracted from sweet corn tassel has a role in inhibiting melanin production, and it is used as an ingredient in skin care whitener [13]. Thus, corn tassel has a significant bioactive property and may be used as a raw material to produce many value-added products at the commercial scale.

The direct collection of corn tassel is a viable method for industrial use and increases the corn production efficiency as waste from corn production is transformed into value-added products. The pigmentations in glume, anther, and pollen grains are important sources of phytochemicals in corn tassel. However, the tassel architecture and the development stage affect the phytochemical yield per unit of production area. In various plants, phytochemical accumulation in plant flowers, such as rose [14], tea [15], safflower [16], and cactus [17], has been shown to be dependent on the development stage.

The information on phytochemicals and antioxidant properties in corn tassel at different development stages is limited. The objective of this study was to investigate the phenolics, anthocyanins, carotenoids, and antioxidant activity at four development stages of corn tassel. The information obtained from this study will be useful for the production of corn tassels as it will help to obtain the highest yield and quality.

\section{Materials and Methods}

\subsection{Plant Material and Sample Preparation}

Eight commercial $\mathrm{F}_{1}$-hybrids in Thailand, including three field corns, two sweet corns, and three waxy corns, were used in this experiment (Table 1). These varieties were selected because of their differences in glume and anther colors (Figure 1). Five uniform tassels were collected at four development stages, including the VT tassel stage(The last branch of the tassel emerged from the whorl, the 1st day of pollen shed, after $50 \%$ of pollen shed, and after $75 \%$ of pollen shed) (Figure 2).

Tassel development stages were considered as factor $\mathrm{A}$, and corn varieties were considered as factor $B$ in a $4 \times 8$ factorial experiment. The corn varieties were planted in a randomized complete block design (RCBD) with three replications in the dry season (October-December, 2015) at the Vegetable Research Station, Khon Kaen University, Thailand. Five whole tassel samples were harvested in 
each plot, cut into small pieces of $2-5 \mathrm{~cm}$, dipped in liquid nitrogen to stop enzymatic activity and freeze-dried. The samples were further homogenized and milled into fine powder by an electric grinder. The particles were screened through a 40-mesh sieve and stored at $-20{ }^{\circ} \mathrm{C}$ until analysis.

Table 1. Source of varieties, corn types, and tassel corn color characteristics.

\begin{tabular}{cccccc}
\hline Entry No. & Varieties & Type & Glume Color & Anther Color & Origin \\
\hline 1 & PAC339 & Field corn & Red-green & Yellow-pink & Pacific Seeds (Thai) Co., Ltd. \\
2 & P4546 & Field corn & Green & Pink & Pioneer Hi-Bred (Thailand) Co., Ltd. \\
3 & S6248 & Field corn & Red-green & Pink & Syngenta Seed Co., Ltd. \\
4 & Hibrix3 & Sweet corn & Green & Yellow & Pacific Seeds (Thai) Co., Ltd. \\
5 & Sugar75 & Sweet corn & Green & Yellow & Syngenta Seed Co., Ltd. \\
6 & Sweet violet & Waxy corn & Green & Light green & East West Seed Co., Ltd. \\
7 & Muang tam & Waxy corn & Red-green & Green-pink & Syngenta Seed Co., Ltd. \\
8 & KGW1 & Waxy corn & Purple-green & Purple & Khon Kaen University \\
\hline
\end{tabular}
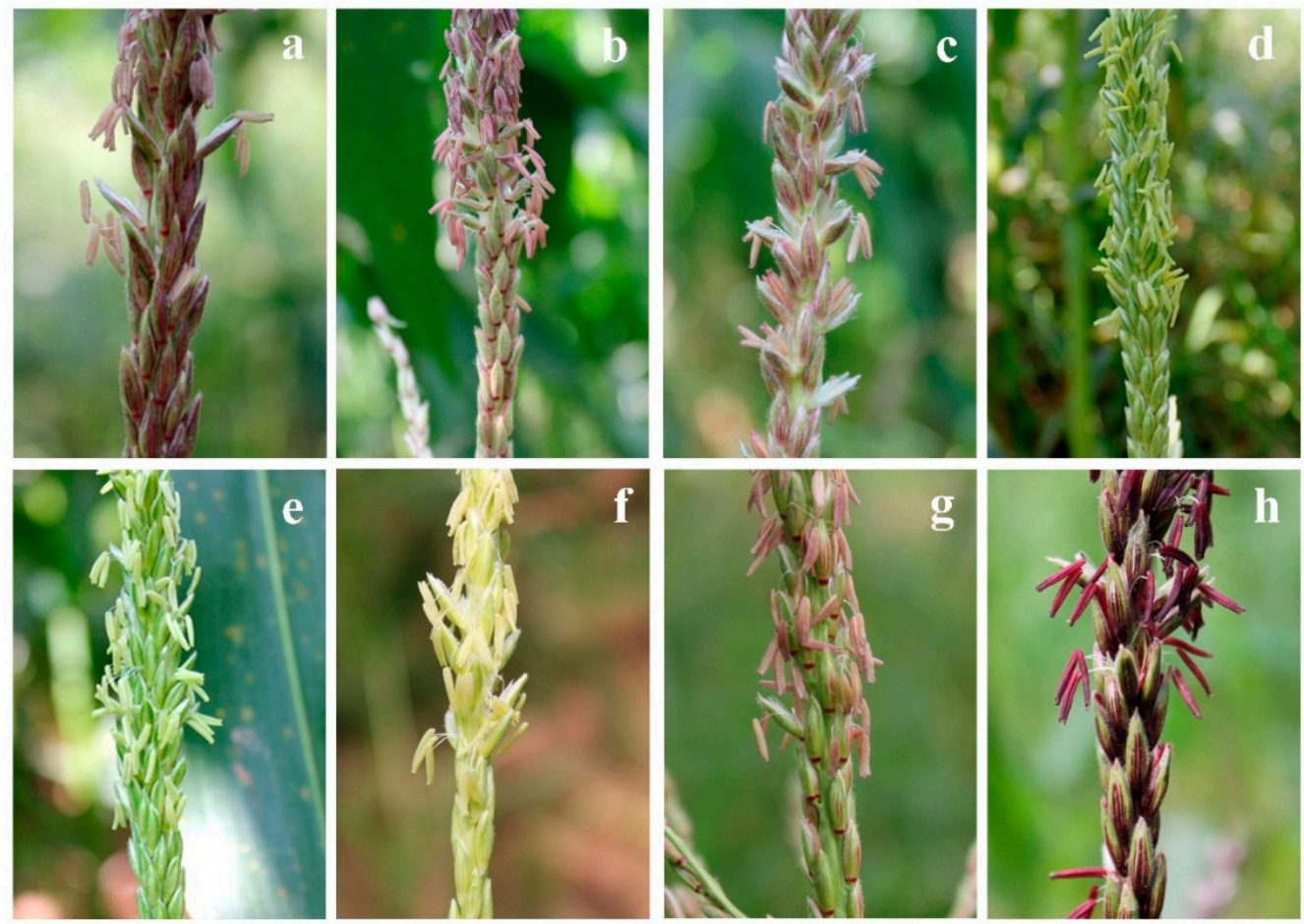

Figure 1. Close-up photographs of the main spike of the tassel of eight commercial hybrids: PAC339 (a), P4546 (b), S6248 (c), Hibrix3 (d), Sugar75 (e), Sweet violet (f), Muang tam (g), and KGW1 (h).
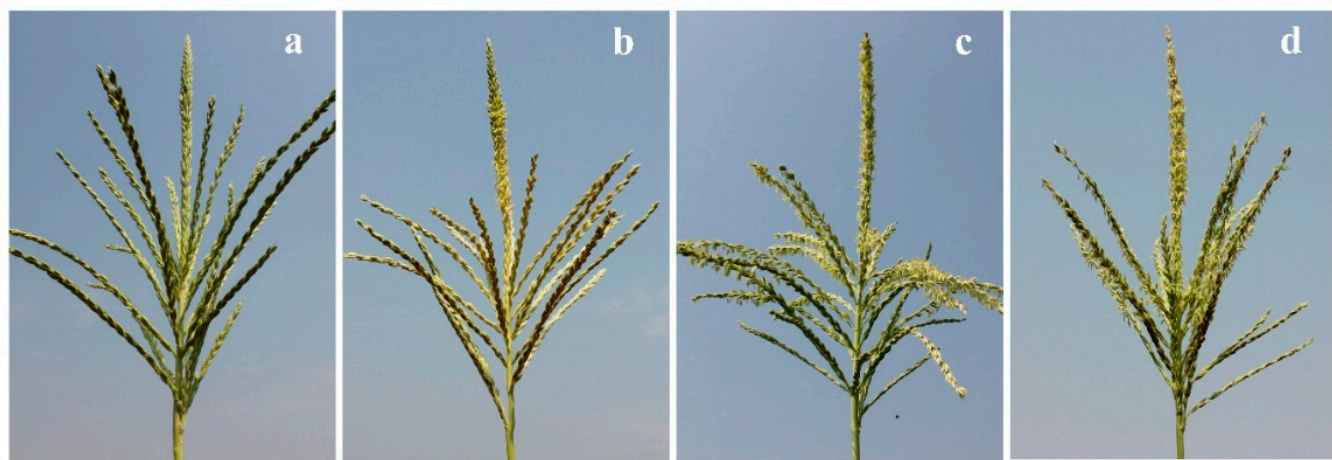

Figure 2. Four stages of corn tassel development: VT tassel (a), 1st day of pollen shed (b), $50 \%$ of pollen shed (c), and $75 \%$ of pollen shed (d). 


\subsection{Chemicals and Reagents}

All chemicals and reagents were of analytical grade. Citric acid, gallic acid, potassium chloride, sodium acetate trihydrate, potassium hydroxide, and methanol were purchased from Ajax Finechem Pty Ltd., Taren Point, New South Wales, Australia. Petroleum ether, diethyl ether, and ethanol were purchased from LCI Labscan Co., Ltd., Bangkok, Thailand. Potassium persulfate, butylated hydroxytoluene (BHT), and Folin-Ciocalteu reagent were purchased from Loba Chemie Pvt. Ltd., Mumbai, India. 2,2-diphenyl-1-picrylhydrazyl (DPPH•), 2,2-azinobis -(3-ethylbenzothiazoline -6-sulfonic acid) (ABTS), and 6-hydroxy -2,5,7,8-tetramethylchroman -2-carboxylic acid (Trolox) were purchased from Sigma-Aldrich Co., St. Louis, MO, USA.

\subsection{Sample Extraction}

The methods used for sample extraction for phenolics and anthocyanins as well as the measurement of antioxidant properties followed those described previously [18] with minor modifications. Briefly, $0.5 \mathrm{~g}$ of the sample was added into $10 \mathrm{~mL}$ of $1 \%$ citric acid (CA) in $80 \%$ methanol $(\mathrm{MeOH})$, and the mixed sample was incubated at $4{ }^{\circ} \mathrm{C}$ for $24 \mathrm{~h}$. The sample was further centrifuged at $5000 \mathrm{rpm}$ for $15 \mathrm{~min}$. The supernatant was filtered through Whatman No.1 filter. The final volumes of the filtrates were adjusted to $10 \mathrm{~mL}$ with extraction solvent and stored at $-20^{\circ} \mathrm{C}$ until analysis.

Sample extraction for carotenoids was carried out according to the method described by Alfieri et al. [19]. Six milliliters of $0.1 \%$ butylated hydroxytoluene (BHT) in ethanol was added into $0.5 \mathrm{~g}$ of the sample. The sample was incubated at $85^{\circ} \mathrm{C}$ for $5 \mathrm{~min}$ and saponified. One hundred and twenty microliters of fresh potassium hydroxide $(\mathrm{KOH}) 17.8 \mathrm{M}$ was added to the sample and incubated at $85^{\circ} \mathrm{C}$ for $10 \mathrm{~min}$. The sample was mixed well, put in an ice bath, and $4 \mathrm{~mL}$ of cold distilled water was added. Then, $3 \mathrm{~mL}$ of 2:1 $(v / v)$ petroleum ether: diethyl ether (PE:DE) was added into the sample, thoroughly mixed, and centrifuged at $2000 \mathrm{rpm}$ for $10 \mathrm{~min}$. After centrifugation, the upper layer of the supernatant was collected, and the remainder of the corn tassel sample was re-extracted 3 times. The total volume of the supernatant was combined and adjusted to $10 \mathrm{~mL}$ with 2:1 PE:DE $(v / v)$.

\subsection{Determination of Total Phenolic Content (TPC)}

TPC was measured by the Folin-Ciocalteu phenol reagent method [20], and it was slightly modified according to the method described by $\mathrm{Hu}$ and $\mathrm{Xu}$ [21]. Briefly, $0.5 \mathrm{~mL}$ of corn tassel extract (described above), $2.5 \mathrm{~mL}$ de-ionized water, and 0.5 of $1 \mathrm{M}$ Folin-Ciocalteu reagent were mixed with a vortex mixer. The mixture was incubated at room temperature for $8 \mathrm{~min}$. After incubation, $1.5 \mathrm{~mL}$ of $7.5 \%$ sodium carbonate was added into the mixture and mixed well using a vortex mixer. The reaction was stored at room temperature for $2 \mathrm{~h}$. The absorbance was measured using a UV-vis spectrophotometer at $765 \mathrm{~nm}$. Gallic acid (GA) solution $(10-100 \mu \mathrm{g} / \mathrm{mL})$ was used to calibrate a standard curve. The TPC was expressed in milligrams of GA equivalent per gramdry weight of the corn tassel sample (mg GAE/g DW sample) and was converted into the total phenolic yield (TPY) per unit of area.

\subsection{Determination of Total Anthocyanin Content (TAC)}

TAC was measured by the $\mathrm{pH}$ differential method [22]. Corn tassel extract was separated into two parts, mixed with $\mathrm{pH} 1.0$ and 4.5 buffer, vortexed, and incubated under dark conditions for $15 \mathrm{~min}$. After incubation, TAC was measured using a UV-vis spectrophotometer at 510 and $700 \mathrm{~nm}$ wavelengths. TAC was calculated with the following formula:

$$
T A C=\frac{A \times M W \times D F \times 1000}{\varepsilon \times 1}
$$


where $A$ is the absorbance of the diluted sample, calculated from $A=\left(A_{510}-A_{700}\right)_{\mathrm{pH} 1.0}-\left(A_{510}-\right.$ $\left.A_{700}\right)_{\mathrm{pH} 4.5}, M W$ is the molecular weight of cyanidin-3-glucoside $(449.2 \mathrm{~g} / \mathrm{mol}), D F$ is the dilution factor, 1000 is a conversion factor from moles to ppm, and the molar absorptivity $(\varepsilon)$ is $26,900 \mathrm{M}^{-1} \mathrm{~cm}^{-1}$. $T A C$ values were expressed as micrograms of cyanidin-3-glucoside equivalent per gram of dry weight of the corn tassel sample ( $\mu \mathrm{g}$ CGE/g DW sample), and the total anthocyanin yield (TAY) per unit of area was calculated.

\subsection{Determination of Total Carotenoid Content (TCC)}

TCC was determined according to the method described previously [23]. The supernatant from the extracted solution was used for the determination of TCC using a UV-vis spectrophotometer at a $450 \mathrm{~nm}$ wavelength. The TCC was calculated using the following equation:

$$
\mathrm{TCC}=\frac{A b s \times 10^{4} \times V}{A_{1 \mathrm{~cm}}^{1 \%} \times W}
$$

where Abs is the absorbance measured at $450 \mathrm{~nm}, V$ is the final volume $(\mathrm{mL}), 104$ is the conversion factor to obtain the concentration in $\mu \mathrm{g}, A_{1 \mathrm{~cm}}^{1 \%}$ is the absorption coefficient (a mean value of 2500 was used), and $W$ is the sample weight (g). The TCC values were expressed as micrograms per gram of dry weight of the corn tassel sample ( $\mu \mathrm{g} / \mathrm{g}$ DW sample), and the total carotenoid yield (TCY) per unit of area was calculated.

\subsection{Determination of Antioxidant Capacity}

The DPPH ${ }^{\bullet}$ radical scavenging assay was analysed by using the original method [24], and the Trolox equivalent antioxidant capacity (TEAC) was analysed by using the method described previously [25] with minor modifications [21]. In the $\mathrm{DPPH}^{\bullet}$ assay, $0.5 \mathrm{~mL}$ of the extracted sample with an appropriate dilution factor was added to $4.5 \mathrm{~mL}$ of $60 \mu \mathrm{M} \mathrm{DPPH}^{\bullet}$, which was dissolved in methanol. The sample was mixed well and set aside for $30 \mathrm{~min}$ in dark conditions. The absorbance was measured at $517 \mathrm{~nm}$, and the solvent was used as a blank. The DPPH radical scavenging rate was calculated with the following equation:

$$
\mathrm{DPPH}^{\bullet} \text { radical scavenging rate }(\%)=\left[1-\left(A b s_{\text {sample }} / A b s_{\text {control }}\right)\right] \times 100
$$

where $A b s_{\text {sample }}$ is the absorbance of the sample extracts and $A b s_{\text {control }}$ is the absorbance of the blank.

In the TEAC assay, the chemicals were mixed with $7 \mathrm{mmol} / \mathrm{L}$ of ABTS and $2.45 \mathrm{mmol} / \mathrm{L}$ of potassium persulfate for preparation of $\mathrm{ABTS}^{\bullet+}$ radical cations. The reaction was mixed well and set aside for 16-24 $\mathrm{h}$ in dark conditions at room temperature before analysis, and this solution was used within 2 days. Then, the $\mathrm{ABTS}^{\bullet+}$ solution was diluted with methanol and the absorbance of $0.700 \pm 0.05 \mathrm{~nm}$ was determined at $734 \mathrm{~nm}$. All sample extracts were diluted to provide $20-80 \%$ inhibition of blank absorbance. Fifty microliters of diluted sample was mixed well with $1.9 \mathrm{~mL}$ of diluted $\mathrm{ABTS}^{\bullet+}$ solution. The final mixture was set aside for $6 \mathrm{~min}$ at room temperature. A UV-vis spectrophotometer was used to measure the optical absorbance values at $734 \mathrm{~nm}$. Trolox solution was used as the standard curve. The results were expressed in micromoles of Trolox equivalent per gram dry weight of the corn tassel sample ( $\mu \mathrm{mol} \mathrm{TE/g} \mathrm{DW} \mathrm{sample).}$

\subsection{Statistical Analysis}

An analysis of variance (ANOVA) was performed for each parameter according to a $4 \times 8$ factorial experiment with RCBD arrangement of the treatments [26]. The statistical model used was $Y_{\mathrm{ijk}}=\mathrm{m}+$ $B_{i}+S_{j}+V_{k}+S_{j k}+e_{i j k}$, where $Y_{i j k}$ is the value of the observational data at the tassel development stage $j$ in variety $k$ and block $i, m$ is the grand mean of the experiment for each parameter, $B_{i}$ is the block effect, $S_{j}$ represents the tassel development stage effects, $V_{k}$ is the variety effects, $S V_{j k}$ is the interaction effect between the tassel development stage and the variety, and $e_{i j k}$ is the pooled error 
effects. The least significant difference (LSD) was used to compare means at $p \leq 0.05$. The results were expressed as mean \pm standard deviation (SD).

\section{Results and Discussion}

\subsection{Variation in Tassel Weight, Phytochemicals and Antioxidant Activity}

The variations observed among tassel development stages and corn varieties were significant $(p \leq 0.01)$ for all parameters (Table 2). In general, variation in varieties contributed to the largest portion of total variationsin most traits (51.9-95.0\%), except in tassel fresh weight in which tassel development had the largest portion (41.3\%). The interactions between the development stage (S) and variety $(\mathrm{V})$ were highly significant $(p \leq 0.01)$ for TAC, TCC, TAY, TCY, and antioxidant activity determined by the TEAC assay. However, the $\mathrm{S} \times \mathrm{V}$ interactions contributed to very small portions of the total variation in these traits.

The results indicate that the effect of variety was the main source of variation in the phytochemicals and antioxidant capacity. The results in this study support those of previous investigations. The main effect of season and the season by genotype interaction contributed to small portions of the total variation in phytochemicals and the antioxidant capacity. The evaluation of corn genotypes for these characteristics over a few seasons was sufficient to identify the superior genotypes [27].

However, the variation in varietal glume and anther colors, ranging from light green to purple (Figure 1), was the most important factor in determining the genetic variability of these phytochemical traits. Pigmentation in plant tissue, especially floral pigments, is a source of many phytochemicals, e.g., chlorophyll, carotenoids, flavonoids, and anthocyanins [28]. The information is important for corn breeders to develop special corn varieties and produce phytochemicals so that food product processors and manufacturers can use this byproduct to develop value-added products. 
Table 2. Mean squares for the tassel weights, phytochemical contents, and antioxidant capacity of eight corn hybrid varieties evaluated at four corn tassel development stages.

\begin{tabular}{|c|c|c|c|c|c|c|c|c|c|c|c|}
\hline \multirow{2}{*}{ Source of Variation } & \multirow{2}{*}{$d f$} & \multicolumn{2}{|c|}{ Tassel Weight } & \multicolumn{3}{|c|}{ Total Phytochemical Content } & \multicolumn{3}{|c|}{ Total Phytochemical Yield } & \multicolumn{2}{|c|}{ Antioxidant Capacity } \\
\hline & & Fresh & Dry & Phenolics & Anthocyanins & Carotenoids & Phenolics & Anthocyanins & Carotenoids & TEAC & DPPH \\
\hline \multirow[t]{2}{*}{ Block } & 2 & 5.56 & 0.24 & 20.15 & 3971 & 477 & 5.04 & 1844 & 80.1 & 728 & 359 \\
\hline & & $(0.6)^{\mathrm{a}}$ & $(0.3)$ & $(5.6)$ & $(0.0)$ & $(3.9)$ & $(4.3)$ & $(0.1)$ & $(2.5)$ & $(6.6)$ & $(7.1)$ \\
\hline \multirow[t]{2}{*}{ Development stages (S) } & 3 & $253.64 * *$ & $15.03^{* *}$ & $15.75 * *$ & 130,783 ** & $1204 * *$ & $15.15^{* *}$ & 25,833 ** & $144.3^{* *}$ & $246^{* *}$ & $212 * *$ \\
\hline & & $(41.3)$ & $(23.9)$ & $(6.6)$ & (1.6) & $(14.6)$ & $(19.2)$ & $(1.3)$ & $(7.0)$ & $(3.4)$ & $(6.3)$ \\
\hline \multirow[t]{2}{*}{ Varieties $(\mathrm{V})$} & 7 & $96.73^{* *}$ & $13.97 * *$ & $64.09 * *$ & $3,385,556^{* *}$ & $2459^{* *}$ & $17.68^{* *}$ & $776,941 * *$ & $635.1^{* *}$ & $2184^{* *}$ & $827 * *$ \\
\hline & & (36.7) & (51.9) & $(62.2)$ & (95.0) & $(69.5)$ & (52.2) & (93.7) & (71.2) & $(69.3)$ & $(57.1)$ \\
\hline \multirow[t]{2}{*}{$\mathrm{S}^{*} \mathrm{~V}$} & 21 & $3.58 \mathrm{~ns}$ & $0.62 n s$ & $2.96 n s$ & $39,989 * *$ & $68^{* *}$ & $1.01 \mathrm{~ns}$ & $11,539 * *$ & $26.9^{* *}$ & $114^{* *}$ & $36 n s$ \\
\hline & & $(4.1)$ & $(6.9)$ & $(8.6)$ & (3.4) & (5.8) & $(9.0)$ & $(4.2)$ & $(9.1)$ & (10.8) & $(7.4)$ \\
\hline \multirow[t]{2}{*}{ Error } & 62 & 5.16 & 0.52 & 1.98 & 364 & 25 & 0.59 & 735 & 10.5 & 35 & 36 \\
\hline & & $(17.3)$ & $(17.0)$ & $(17.0)$ & $(0.1)$ & 6.25 & (15.4) & $(0.8)$ & $(10.2)$ & $(9.9)$ & $(22.1)$ \\
\hline C.V. $(\%)$ & & 8.54 & 8.43 & 11.70 & 6.78 & 10.67 & 14.81 & 21.30 & 16.24 & 10.15 & 7.56 \\
\hline
\end{tabular}

$d f$ : degrees of freedom, C.V.: coefficient of variation, TEAC: Trolox equivalent antioxidant capacity, DPPH: 2,2-diphenyl-1-picrylhydrazyl radical scavenging capacity. ${ }^{a}$ Number in parentheses is percentage of the sum of squares. $n s$ : non-significant, ${ }^{* *}$ significant at $p \leq 0.01$. 


\subsection{Effect of Development Stages on Tassel Weight and Phenolic Compounds}

The VT tassel and the 1st day of pollen shed stages had the highest tassel fresh weights of 28.2 and $29.4 \mathrm{~g}$, respectively, whereas the 1st day of pollen shed had the highest tassel dry weight of $9.4 \mathrm{~g}$ (Figure 3). These results are similar to those of a previous study. Hybrid corn varieties had increased tassel dry weights from tassel emergence to the first pollen shed. The tassel weight was highest before pollen shed and, then, it gradually reduced until pollen shed was completed [29]. The tassel weight continued to decrease after pollen shed. The reduction in tassel weight would be possibly due to the loss of pollen grains. However, the quantity of pollen production in corn tassels was depended on the tassel structure in different corn varieties, such as the number of tassel branches, the tassel length, the length of anthers, the number of spikelets, and thetassel area index. The number of tassel branches and number of spikelets are important traits of tassel architecture as these traits were correlated with pollen production [30].
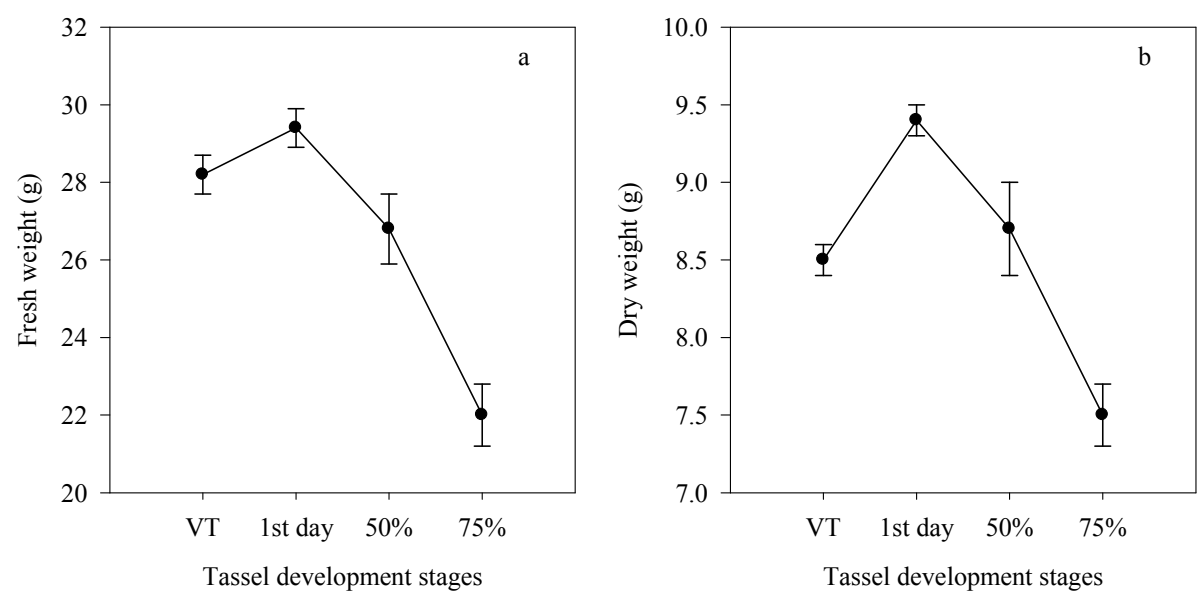

Figure 3. Effect of corn tassel development stages on tassel fresh weight (a) and tassel dry weight (b).

Corn varieties had significantly different $(p \leq 0.01)$ tassel fresh weights. Hibrix3 had the highest tassel fresh weight (31.2 g) followed by Sugar75 and KGW1 (29.2 and 28.8 g, respectively) (Table 3). These varieties also had high tassel dry weights. The tassel fresh weight and tassel dry weight across development stages showed similar patterns. However, modern field corn hybrids had smaller tassels than older corn hybrids, and smaller tassels reduce light interception and improve grain production efficiency at a high plant density [31].

Differences among development stages were observed for TPC, ranging from 11.1 to $13.0 \mathrm{mg}$ GAE/g DW sample. The 1st day of pollen shed had the highest TPC of $13.0 \mathrm{mg}$ GAE/g DW sample, followed by the VT tassel and 50\% pollen shed stages. Based on the yield per unit of area, the TPY ranged from 4.18 to $6.13 \mathrm{~kg} \mathrm{GAE} / \mathrm{ha}$, showing a similar trend to the TPC (Figure 4a,b). The P4546 field corn had the highest TPC of $15.8 \mathrm{mg}$ GAE/g DW sample followed by Hibrix3 sweet corn, and S6248 and PAC339 field corn (13.4, 12.9, and $12.8 \mathrm{mg} \mathrm{GAE} / \mathrm{g}$ DW sample, respectively) (Table 3). Hibrix3 had the highest TPY of $6.78 \mathrm{~kg} \mathrm{GAE} /$ ha because this sweet corn has big tassels and a high tassel weight.

Modern field corn breeding has focused on the improvement of adaptability to climate change, drought tolerance, disease resistance, and insect resistance. These characteristics may affect phenolic accumulation in field corn because phenolic acids play a key role as defense compounds in response to environmental stresses such as water stress, low temperature, high solar radiation, pathogenic infection, and nutrient deficiency [32].

Plant phenolics are the most widely distributed natural secondary metabolites in plant phyla. Flavonoids are very large sub-groups of the phenolic compounds and play an important role in functional pollen development. The synthetic pathway of plant phenolics is controlled by development and environmental signals [33]. Oxidative stress and production of relative oxygen species are induced 
by stresses and these factors affect the proteins, DNA, and lipids of plant cells. Lipid peroxidation has a harmful and damaging effect on cell membranes. Simultaneously, lipid peroxidation also plays a role as a signaling molecule through theproline-linked pentose phosphate pathway for biosynthesis of secondary metabolites, and the resulting secondary metabolites are important for the protection of cell membranes from oxidative stress [34].

Table 3. Means for tassel fresh weight, tassel dry weight, total phenolic content, and total phenolic yield in the tassels of eight corn varieties.

\begin{tabular}{|c|c|c|c|c|}
\hline \multirow[b]{2}{*}{ Varieties } & \multicolumn{2}{|c|}{ Tassel Weight } & \multicolumn{2}{|c|}{ Phenolic Compounds } \\
\hline & Fresh (g) & Dry (g) & $\begin{array}{l}\text { Total Phenolic Content } \\
\text { (mg GAE/g DW Sample) }\end{array}$ & $\begin{array}{l}\text { Total Phenolic Yield } \\
\text { (kg GAE/ha) }\end{array}$ \\
\hline \multicolumn{5}{|l|}{ Field corn } \\
\hline PAC339 & $26.5 \pm 1.9 c$ & $8.7 \pm 0.6 b$ & $12.8 \pm 0.7 \mathrm{bc}$ & $5.59 \pm 0.7 \mathrm{~b}$ \\
\hline P4546 & $23.4 \pm 0.7 \mathrm{~d}$ & $7.3 \pm 0.2 \mathrm{~d}$ & $15.8 \pm 1.1 \mathrm{a}$ & $5.80 \pm 0.5 \mathrm{~b}$ \\
\hline S6248 & $24.2 \pm 0.9 \mathrm{~d}$ & $8.2 \pm 0.3 b c$ & $12.9 \pm 1.4 \mathrm{bc}$ & $5.34 \pm 0.4 b$ \\
\hline Mean & 24.7 & 8.1 & 13.8 & 5.58 \\
\hline \multicolumn{5}{|l|}{ Sweet corn } \\
\hline Hibrix3 & $31.2 \pm 2.4 \mathrm{a}$ & $10.1 \pm 0.6 \mathrm{a}$ & $13.4 \pm 1.2 \mathrm{bc}$ & $6.78 \pm 1.0 \mathrm{a}$ \\
\hline Sugar75 & $29.2 \pm 1.7 b$ & $9.5 \pm 0.4 \mathrm{a}$ & $11.0 \pm 0.6 \mathrm{~d}$ & $5.25 \pm 0.1 b$ \\
\hline Mean & 30.2 & 9.8 & 12.2 & 6.01 \\
\hline \multicolumn{5}{|l|}{ Waxy corn } \\
\hline Sweet violet & $24.4 \pm 0.2 \mathrm{~d}$ & $7.2 \pm 0.1 \mathrm{~d}$ & $8.4 \pm 0.6 \mathrm{f}$ & $3.02 \pm 0.2 \mathrm{~d}$ \\
\hline Muang tam & $24.9 \pm 0.9 \mathrm{~cd}$ & $7.7 \pm 0.2 \mathrm{~cd}$ & $9.7 \pm 0.9 \mathrm{e}$ & $3.75 \pm 0.4 \mathrm{c}$ \\
\hline KGW1 & $28.8 \pm 0.3 \mathrm{~b}$ & $9.5 \pm 0.5 \mathrm{a}$ & $12.2 \pm 1.8 \mathrm{c}$ & $5.86 \pm 0.9 b$ \\
\hline Mean & 26.0 & 8.2 & 10.1 & 4.21 \\
\hline
\end{tabular}

Data are expressed as the mean $\pm \mathrm{SD}$ of three replicates. Means with the same letter(s) in the same column are not significantly different $(p \leq 0.05)$, as determined by LSD.

\subsection{Anthocyanins in Corn Tassels}

The TAC in corn tassels increased consistently from the VT tassel stage to the later stages of flower development. The $75 \%$ of pollen shed stage had the highest TAC of $343.1 \mu \mathrm{g}$ CGE/g DW sample, followed by the $50 \%$ of pollen shed and 1st day of pollen shed stages, whereas the 1st day ofpollen shed and $50 \%$ of pollen shed stages had the highest TAY values of 155.0 and $142.6 \mathrm{~g}$ CGE/ha, respectively (Figure $4 \mathrm{c}, \mathrm{d}$ ). On average, across the development stages and varieties, TAC values ranged from 11.1 to $1864.6 \mu \mathrm{g}$ CGE/g DW sample. KGW1 had the highest TAC of $1864.6 \mu \mathrm{g}$ CGE/g DW sample at $75 \%$ of pollen shed followed by the $50 \%$ of pollen shed, 1st day of pollen shed, and VT tassel stages (1716.6, 1647.2, and 1099.3 $\mu \mathrm{g}$ CGE/g DW sample, respectively). TAY was closely related to the tassel dry weight, and KGW1 of purple waxy corn was a superior variety for TAY as it maintained the highest TAY at the 50\% of pollen shed and 1st day of pollen shed stages (898.7 and $873.4 \mathrm{~g}$ CGE/ha, respectively) (Table 4 ).

The aims of this research project were to find suitable times for corn tassel harvest and suitable corn types and varieties for the production of corn pollen with a high anthocyanin content in the tassels that are appropriate for use as a raw material for functional food products. The hypothesis underlying the research project was that theanthocyanin level in corn tassels is related to the purple color of the glumes and anthers in different corn types and varieties and at development stage of corn tassel development. In our earlier work, in other corn parts, TAC increased from the milky stage to the maturity stage in waxy corn kernels and was highest in purplish black-colored genotypes [35]. A similar increase in anthocyanins in purple corn silk was also observed from the silking stage to the milky stage, but it decreased slightly at the maturity stage [1]. Moreover, the anthocyanin concentration in purple corn was affected by several factors such as the genotype, growing location, extraction solvent, and determination method. These factors should be considered for the production of anthocyanin from corn tassels for industrial use. 
Table 4. Means for total anthocyanin content and total anthocyanin yield in the tassels of eight corn varieties evaluated at four tassel development stages.

\begin{tabular}{|c|c|c|c|c|c|}
\hline \multirow[b]{2}{*}{ Varieties } & \multicolumn{5}{|c|}{ Tassel Development Stages } \\
\hline & VT Tassel & $\begin{array}{l}\text { 1st day of } \\
\text { Pollen Shed }\end{array}$ & $\begin{array}{c}50 \% \text { of } \\
\text { Pollen Shed }\end{array}$ & $\begin{array}{c}75 \% \text { of } \\
\text { Pollen Shed }\end{array}$ & Mean \\
\hline \multicolumn{6}{|c|}{ Total Anthocyanin Content ( $\mu$ g CGE/g DW Sample) } \\
\hline \multicolumn{6}{|l|}{ Field corn } \\
\hline PAC339 & $76.0 \pm 4.2 \mathrm{kl}$ & $84.2 \pm 5.5 \mathrm{j}-1$ & $219.3 \pm 17.2 \mathrm{fg}$ & $208.0 \pm 2.5 \mathrm{~g}$ & $146.9 \pm 4.6 \mathrm{C}$ \\
\hline P4546 & $59.8 \pm 6.6 \mathrm{~lm}$ & $244.6 \pm 43.6 \mathrm{f}$ & $338.9 \pm 46.5 \mathrm{e}$ & $325.0 \pm 22.9 \mathrm{e}$ & $242.1 \pm 26.7$ B \\
\hline S6248 & $93.9 \pm 28.3 \mathrm{jk}$ & $132.5 \pm 49.5 \mathrm{i}$ & $128.1 \pm 8.8 \mathrm{i}$ & $176.5 \pm 4.8 \mathrm{~h}$ & $132.7 \pm 20.4 \mathrm{C}$ \\
\hline Mean & 76.6 & 153.8 & 228.8 & 236.5 & 173.9 \\
\hline \multicolumn{6}{|l|}{ Sweet corn } \\
\hline Hibrix3 & $26.4 \pm 2.5$ no & $18.1 \pm 6.4$ no & $17.4 \pm 8.1$ no & $16.7 \pm 9.8$ no & $19.6 \pm 6.7 \mathrm{E}$ \\
\hline Sugar75 & $12.7 \pm 6.4$ no & $39.1 \pm 2.9 \mathrm{~m}-\mathrm{o}$ & $23.1 \pm 1.4$ no & $27.4 \pm 6.5$ no & $25.6 \pm 2.1 \mathrm{E}$ \\
\hline Mean & 19.6 & 28.6 & 20.3 & 22.1 & 22.6 \\
\hline \multicolumn{6}{|l|}{ Waxy corn } \\
\hline Sweet violet & $11.5 \pm 2.5$ no & $11.1 \pm 0.8$ о & $18.7 \pm 2.7$ no & $17.9 \pm 3.6$ no & $14.8 \pm 2.0 \mathrm{E}$ \\
\hline Muang tam & $42.3 \pm 15.3 \mathrm{mn}$ & $80.3 \pm 6.7 \mathrm{j}-\mathrm{k}$ & $127.9 \pm 6.5 \mathrm{i}$ & $108.9 \pm 7.5 \mathrm{ij}$ & $89.9 \pm 5.7 \mathrm{D}$ \\
\hline KGW1 & $1099.3 \pm 44.0 \mathrm{~d}$ & $1647.2 \pm 25.1 \mathrm{c}$ & $1716.6 \pm 35.5 b$ & $1864.6 \pm 49.3 \mathrm{a}$ & $1582.0 \pm 38.5 \mathrm{~A}$ \\
\hline Mean & 384.4 & 579.5 & 621.1 & 663.8 & 562.2 \\
\hline \multicolumn{6}{|c|}{ Total Anthocyanin Yield (g CGE/ha) } \\
\hline \multicolumn{6}{|l|}{ Field corn } \\
\hline PAC339 & $33.6 \pm 1.5 \mathrm{~h}-\mathrm{k}$ & $39.5 \pm 1.7 \mathrm{~h}-\mathrm{k}$ & $88.6 \pm 11.5 \mathrm{~d}-\mathrm{g}$ & $86.6 \pm 10.5 \mathrm{~d}-\mathrm{g}$ & $62.1 \pm 4.2 \mathrm{C}$ \\
\hline P4546 & $22.5 \pm 1.9 \mathrm{~h}-\mathrm{k}$ & $99.9 \pm 21.3 \mathrm{~d}-\mathrm{f}$ & $121.2 \pm 8.8 \mathrm{~d}$ & $105.4 \pm 17.2 \mathrm{de}$ & $87.2 \pm 11.0 \mathrm{~B}$ \\
\hline S6248 & $40.4 \pm 10.9 \mathrm{~h}-\mathrm{k}$ & $58.1 \pm 23.4 \mathrm{f}-\mathrm{j}$ & $52.6 \pm 6.8 \mathrm{~g}-\mathrm{j}$ & $64.8 \pm 5.6 \mathrm{e}-\mathrm{h}$ & $54.0 \pm 9.0 \mathrm{CD}$ \\
\hline Mean & 32.2 & 65.8 & 87.5 & 85.6 & 67.8 \\
\hline \multicolumn{6}{|l|}{ Sweet corn } \\
\hline Hibrix3 & $13.3 \pm 2.1 \mathrm{jk}$ & $10.1 \pm 4.3 \mathrm{jk}$ & $9.3 \pm 4.8 \mathrm{jk}$ & $7.2 \pm 4.4 \mathrm{k}$ & $10.0 \pm 3.9 \mathrm{E}$ \\
\hline Sugar75 & $6.0 \pm 2.8 \mathrm{k}$ & $20.7 \pm 1.8 \mathrm{~h}-\mathrm{k}$ & $11.6 \pm 1.8 \mathrm{jk}$ & $10.7 \pm 2.4 \mathrm{jk}$ & $12.2 \pm 0.5 \mathrm{E}$ \\
\hline Mean & 9.6 & 15.4 & 10.4 & 9.0 & 11.1 \\
\hline \multicolumn{6}{|l|}{ Waxy corn } \\
\hline Sweet violet & $3.9 \pm 0.7 \mathrm{k}$ & $4.5 \pm 0.3 \mathrm{k}$ & $6.7 \pm 1.2 \mathrm{k}$ & $6.0 \pm 0.7 \mathrm{k}$ & $5.3 \pm 0.6 \mathrm{E}$ \\
\hline Muang tam & $16.6 \pm 7.5 \mathrm{i}-\mathrm{k}$ & $34.5 \pm 3.4 \mathrm{~h}-\mathrm{k}$ & $51.6 \pm 6.4 \mathrm{~g}-\mathrm{j}$ & $35.9 \pm 3.5 \mathrm{~h}-\mathrm{k}$ & $34.7 \pm 2.5 \mathrm{D}$ \\
\hline KGW1 & $506.1 \pm 61.1 \mathrm{c}$ & $873.4 \pm 114.5 \mathrm{a}$ & $898.7 \pm 50.4 \mathrm{a}$ & $733.7 \pm 56.8 b$ & $753.0 \pm 48.1 \mathrm{~A}$ \\
\hline Mean & 175.5 & 304.1 & 319.0 & 258.6 & 264.3 \\
\hline
\end{tabular}

CGE: cyanidin 3-glucoside equivalent. Data are expressed as the mean \pm SD of three replicates. Means with the same letter(s) in the same column are not significantly different $(p \leq 0.05)$, as determined by LSD.

\subsection{Carotenoids in Corn Tassels}

The TCC among development stages ranged from 39.9 to $54.1 \mu \mathrm{g} / \mathrm{g}$ DW sample. The $50 \%$ of pollen shed and $75 \%$ of pollen shed stages had the highest TCC values of 51.7 and $54.1 \mu \mathrm{g} / \mathrm{g}$ DW sample, respectively, whereas the stage of $50 \%$ of pollen shed stage had the highest TCY of $22.9 \mathrm{~g} / \mathrm{ha}$, followed by the $75 \%$ of pollen shed, 1st day of pollen shed, and VT tassel stages $(20.3,19.7$, and $17.0 \mathrm{~g} / \mathrm{ha}$, respectively) (Figure 4e,f). These results suggest that pollen shedding affects the tassel weight and leads to a decreased carotenoid yield in the late stages of tassel development.

Variations in TCC and TAC followed a similar pattern across the stages of tassel development and corn varieties. TCC ranged from 26.1 to $88.4 \mu \mathrm{g} / \mathrm{g}$ DW sample. KGW1 had the highest TCC of 88.4 and $85.7 \mu \mathrm{g} / \mathrm{g}$ DW sample at $50 \%$ of pollen shed and $75 \%$ of pollen shed, respectively. TCY ranged from 8.2 to $46.3 \mathrm{~g} / \mathrm{ha}$ across the stages of tassel development and corn varieties, and KGW1 had the highest TCY value of $46.3 \mathrm{~g} / \mathrm{ha}$ at $50 \%$ of pollen shed, followed by the 1 st day of pollen shed ( $35.8 \mathrm{~g} / \mathrm{ha}$ ) and $75 \%$ of pollen shed ( $33.6 \mathrm{~g} / \mathrm{ha}$ ) stages (Table 5$)$. 
In general, pollen, petals, and fruits have high levels of carotenoids. Pollen is an important source of carotenoids in several crops, such as calendula, marigold, and chamomile [36]. According to Bogdanov [37], beta carotene is the main carotenoid compound in pollen, with contents ranging from 10 to $200 \mu \mathrm{g} / \mathrm{g}$ sample (17\%) recorded. The total carotenoid contents in corn tassels in this study were higher than those reported previously in the kernels of yellow-orange corn from Nigeria [38], Italy [19], and central Malawi [39]. The results indicated that corn tassel could be used as a new source of carotenoids for functional food supplements. The collection of corn flower pollen is more convenient and productive than the collection of bee pollen.

Table 5. Means of the total carotenoid content and total carotenoid yield in the tassels of eight corn varieties evaluated at four tassel development stages.

\begin{tabular}{|c|c|c|c|c|c|}
\hline \multirow[b]{2}{*}{ Varieties } & \multicolumn{5}{|c|}{ Tassel Development Stages } \\
\hline & VT Tassel & $\begin{array}{l}\text { 1st Day of } \\
\text { Pollen Shed }\end{array}$ & $\begin{array}{c}50 \% \text { of } \\
\text { Pollen Shed }\end{array}$ & $\begin{array}{c}75 \% \text { of } \\
\text { Pollen Shed }\end{array}$ & Mean \\
\hline \multicolumn{6}{|c|}{ Total Carotenoid Content ( $\mu$ g/g DW Sample) } \\
\hline \multicolumn{6}{|l|}{ Field corn } \\
\hline PAC339 & $32.0 \pm 5.8 \mathrm{o}-\mathrm{r}$ & $31.9 \pm 4.2 \mathrm{o}-\mathrm{r}$ & $49.3 \pm 10.6 \mathrm{e}-\mathrm{j}$ & $50.6 \pm 5.7 \mathrm{~d}-\mathrm{g}$ & $41.0 \pm 4.5 \mathrm{D}$ \\
\hline P4546 & $23.7 \pm 5.2 \mathrm{~s}$ & $31.3 \pm 8.4 \mathrm{o}-\mathrm{s}$ & $34.6 \pm 8.2 \mathrm{~m}-\mathrm{q}$ & $38.5 \pm 5.8 \mathrm{k}-\mathrm{m}$ & $32.0 \pm 6.6 \mathrm{E}$ \\
\hline S6248 & $33.8 \pm 7.4 \mathrm{n}-\mathrm{r}$ & $29.8 \pm 5.5 \mathrm{p}-\mathrm{s}$ & $36.4 \pm 4.61-\mathrm{p}$ & $41.6 \pm 5.9 j-n$ & $35.4 \pm 5.4 \mathrm{E}$ \\
\hline Mean & 29.8 & 31.0 & 40.1 & 43.6 & 36.1 \\
\hline \multicolumn{6}{|l|}{ Sweet corn } \\
\hline Hibrix3 & $26.8 \pm 5.9 \mathrm{q}-\mathrm{s}$ & $26.1 \pm 5.4 \mathrm{rs}$ & $43.9 \pm 10.0 \mathrm{~g}-1$ & $41.7 \pm 3.4 \mathrm{i}-\mathrm{n}$ & $34.6 \pm 6.1 \mathrm{E}$ \\
\hline Sugar75 & $47.8 \pm 1.8 \mathrm{f}-\mathrm{j}$ & $46.9 \pm 9.9 \mathrm{f}-\mathrm{j}$ & $46.5 \pm 5.5 \mathrm{f}-\mathrm{k}$ & $56.4 \pm 2.7 \mathrm{c}-\mathrm{e}$ & $49.4 \pm 3.6 \mathrm{C}$ \\
\hline Mean & 37.3 & 36.5 & 45.2 & 49.1 & 42.0 \\
\hline \multicolumn{6}{|l|}{ Waxy corn } \\
\hline Sweet violet & $54.3 \pm 3.4 \mathrm{c}-\mathrm{f}$ & $50.3 \pm 3.4 \mathrm{e}-\mathrm{h}$ & $59.5 \pm 3.7 \mathrm{bc}$ & $61.4 \pm 7.8 \mathrm{bc}$ & $56.4 \pm 3.3 \mathrm{~B}$ \\
\hline Muang tam & $42.4 \pm 6.3 \mathrm{~h}-\mathrm{m}$ & $49.8 \pm 6.8 \mathrm{e}-\mathrm{i}$ & $54.5 \pm 2.7 \mathrm{c}-\mathrm{f}$ & $56.5 \pm 5.3 c-e$ & $50.8 \pm 4.6 \mathrm{C}$ \\
\hline KGW1 & $58.5 \pm 7.6 \mathrm{~cd}$ & $66.9 \pm 6.3 b$ & $88.4 \pm 4.3 \mathrm{a}$ & $85.7 \pm 8.0 \mathrm{a}$ & $74.9 \pm 6.2 \mathrm{~A}$ \\
\hline mean & 51.7 & 55.7 & 67.5 & 67.9 & 60.7 \\
\hline \multicolumn{6}{|c|}{ Total Carotenoid Yield (g/ha) } \\
\hline \multicolumn{6}{|l|}{ Field corn } \\
\hline PAC339 & $14.0 \pm 1.4 \mathrm{j}-\mathrm{m}$ & $15.1 \pm 2.6 \mathrm{~h}-1$ & $19.8 \pm 4.4 \mathrm{~d}-\mathrm{i}$ & $21.2 \pm 4.8 \mathrm{~d}-\mathrm{g}$ & $17.5 \pm 2.3 \mathrm{D}$ \\
\hline P4546 & $8.9 \pm 2.0 \mathrm{~m}$ & $12.7 \pm 3.6 \mathrm{k}-\mathrm{m}$ & $12.5 \pm 3.2 \mathrm{~lm}$ & $12.6 \pm 3.11-\mathrm{m}$ & $11.7 \pm 2.8 \mathrm{E}$ \\
\hline S6248 & $14.6 \pm 2.8 \mathrm{i}-1$ & $13.0 \pm 3.1 \mathrm{k}-\mathrm{m}$ & $15.0 \pm 2.4 \mathrm{~h}-1$ & $15.2 \pm 1.2 \mathrm{~h}-1$ & $14.4 \pm 2.1 \mathrm{E}$ \\
\hline Mean & 12.5 & 13.6 & 15.8 & 16.3 & 14.6 \\
\hline \multicolumn{6}{|l|}{ Sweet corn } \\
\hline Hibrix3 & $13.5 \pm 3.9 \mathrm{j}-\mathrm{m}$ & $14.4 \pm 3.5 \mathrm{j}-1$ & $23.6 \pm 7.4 \mathrm{c}-\mathrm{e}$ & $18.0 \pm 2.4 \mathrm{f}-\mathrm{k}$ & $17.4 \pm 4.3 \mathrm{D}$ \\
\hline Sugar75 & $22.7 \pm 2.0 \mathrm{c}-\mathrm{f}$ & $24.8 \pm 4.8 \mathrm{~cd}$ & $23.2 \pm 3.2 \mathrm{c}-\mathrm{f}$ & $22.0 \pm 0.6 \mathrm{c}-\mathrm{f}$ & $23.2 \pm 2.2 \mathrm{~B}$ \\
\hline Mean & 18.1 & 23.4 & 23.4 & 20.0 & 20.3 \\
\hline \multicolumn{6}{|l|}{ Waxy corn } \\
\hline Sweet violet & $18.5 \pm 2.1 \mathrm{e}-\mathrm{j}$ & $21.2 \pm 1.5 \mathrm{~d}-\mathrm{h}$ & $21.2 \pm 1.2 \mathrm{~d}-\mathrm{g}$ & $20.9 \pm 3.9 \mathrm{~d}-\mathrm{g}$ & $20.2 \pm 1.1 \mathrm{C}$ \\
\hline Muang tam & $16.2 \pm 2.7 \mathrm{~g}-1$ & $21.9 \pm 3.4 \mathrm{~d}-\mathrm{g}$ & $21.9 \pm 1.6 \mathrm{~d}-\mathrm{f}$ & $18.7 \pm 2.7 \mathrm{e}-\mathrm{j}$ & $19.6 \pm 1.8 \mathrm{CD}$ \\
\hline KGW1 & $27.2 \pm 6.1 \mathrm{c}$ & $35.8 \pm 7.7 \mathrm{~b}$ & $46.3 \pm 3.7 \mathrm{a}$ & $33.6 \pm 2.5 \mathrm{~b}$ & $35.7 \pm 4.3 \mathrm{~A}$ \\
\hline Mean & 20.6 & 29.8 & 29.8 & 24.4 & 25.2 \\
\hline
\end{tabular}

Data are expressed as the mean \pm SD of three replicates. Means with the same letter(s) in the same column are not significantly different $(p \leq 0.05)$, as determined by LSD. 

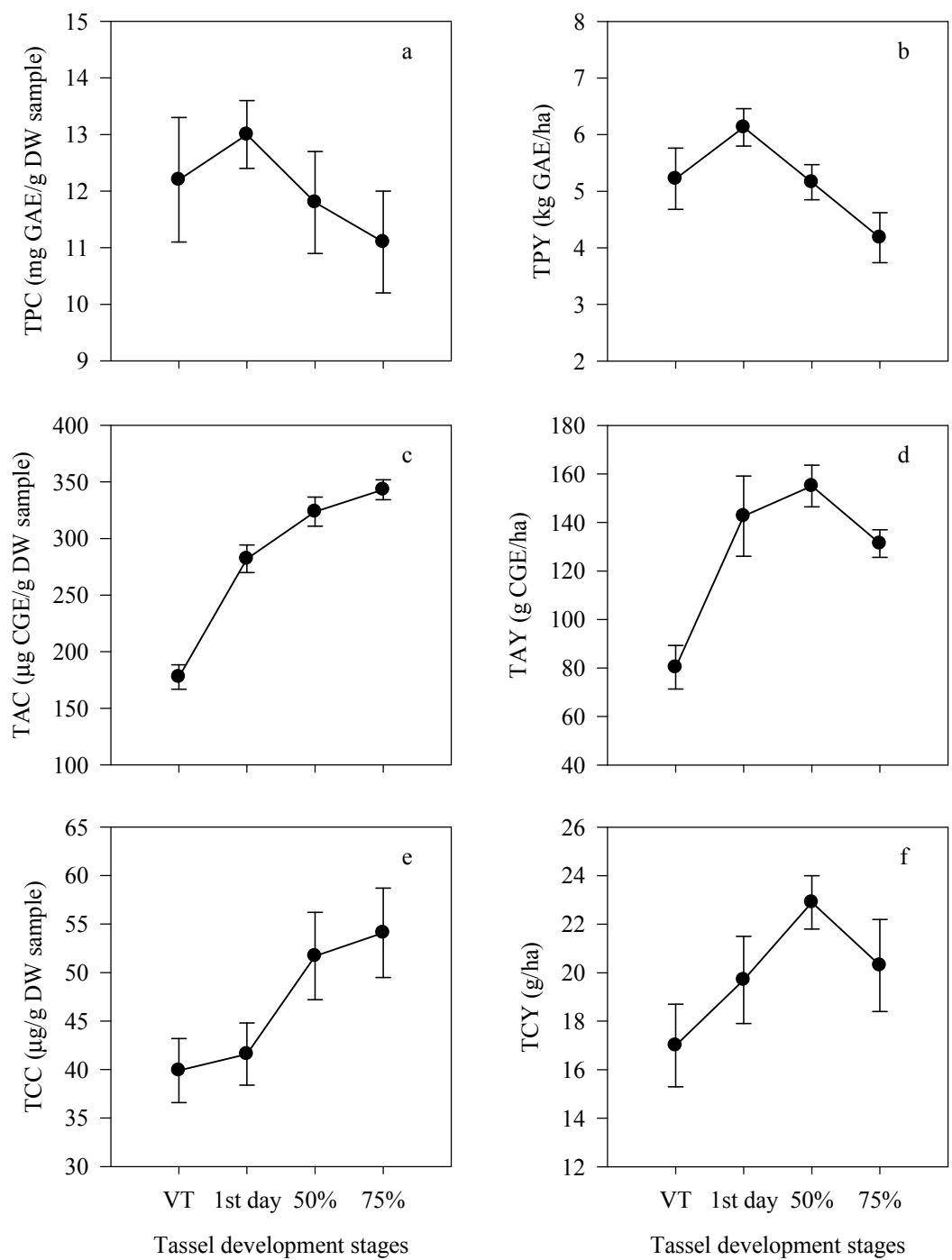

Figure 4. Effects of the corn tassel development stage on the total phenolic content (a), total phenolic yield (b), total anthocyanin content (c), total anthocyanin yield (d), total carotenoid content (e), and total carotenoid yield (f).

\subsection{Antioxidant Capacity in Corn Tassels}

The results from the DPPH ${ }^{\bullet}$ and TEAC methods provided similar information about antioxidant activity. The pollen harvested at $75 \%$ of pollen shed had the lowest antioxidant capacity. Antioxidant capacity values determined by the $\mathrm{DPPH}^{\bullet}$ method ranged from 75.4 to $81.8 \%$ (Figure 5a). P4546 also had the highest level of DPPH ${ }^{\bullet}$ radical scavenging activity (92.4\%) followed by PAC339 (87.3\%), S6248 $(82.0 \%)$, and KGW1 (78.3\%), respectively (Figure 6).

The antioxidant capacity was closely related to TPC especially for field corn, as illustrated by the results for P4546. The results in this study were in agreement with those in a previous report of the cobs, husks, and silks of corn. TPC was also closely related to the antioxidant capacity, as determined by the $\mathrm{DPPH}^{\bullet}$ method and $\mathrm{ABTS}^{\bullet+}$ method $(r=0.709$ and $r=0.871$, respectively) [3]. The range of values measured by the $\mathrm{DPPH}^{\bullet}$ radical scavenging assay in this study was comparable to those from a previous report using different extraction solvents including ethanol (83.0-85.2\%), methanol (69.9-83.7\%), and acetone (69.8-80.4\%) [11]. Moreover, the antioxidant capacity values in corn tassel determined by the $\mathrm{DPPH}^{\bullet}$ method, which ranged from 54.9 to $78.3 \%$, were similar in purple waxy and super sweet corn silk, but they were higher than those in white waxy corn silk [1]. 

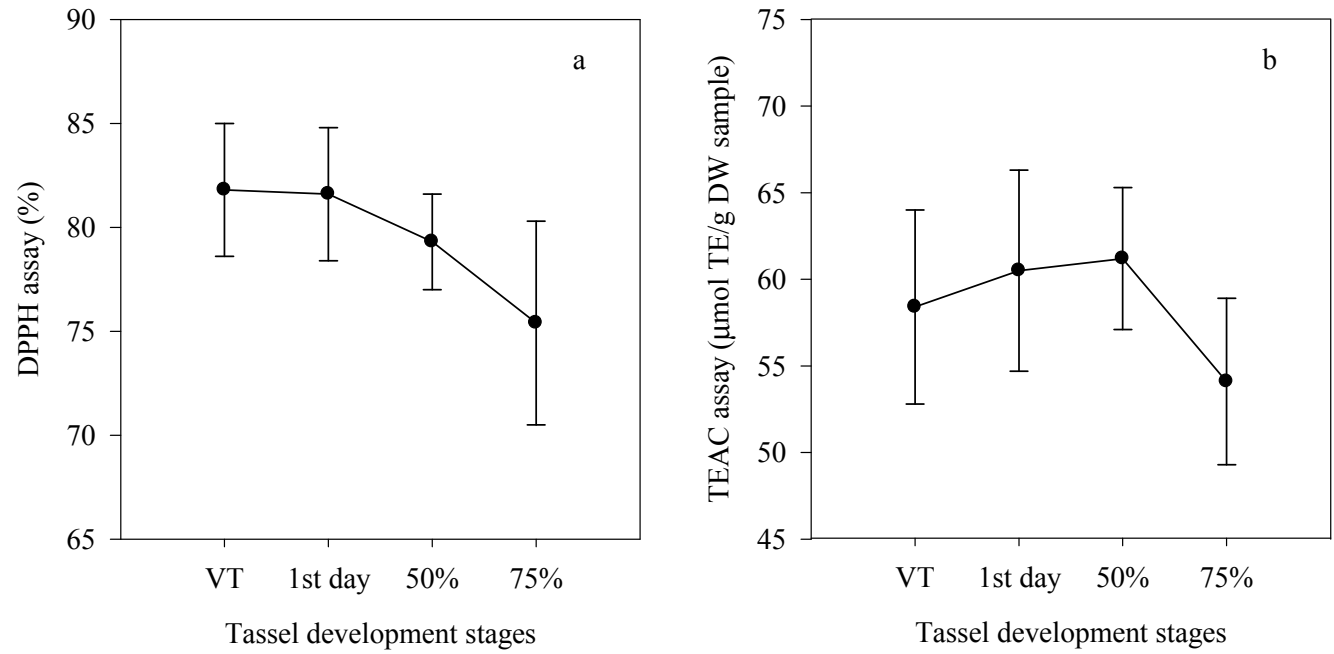

Figure 5. Effects of corn tassel development stages on the antioxidant capacity, as determined by 2,2-diphenyl-1-picrylhydrazyl (DPPH) radical scavenging capacity assay (a) and Trolox equivalent antioxidant capacity (TEAC) radical scavenging capacity assay (b).

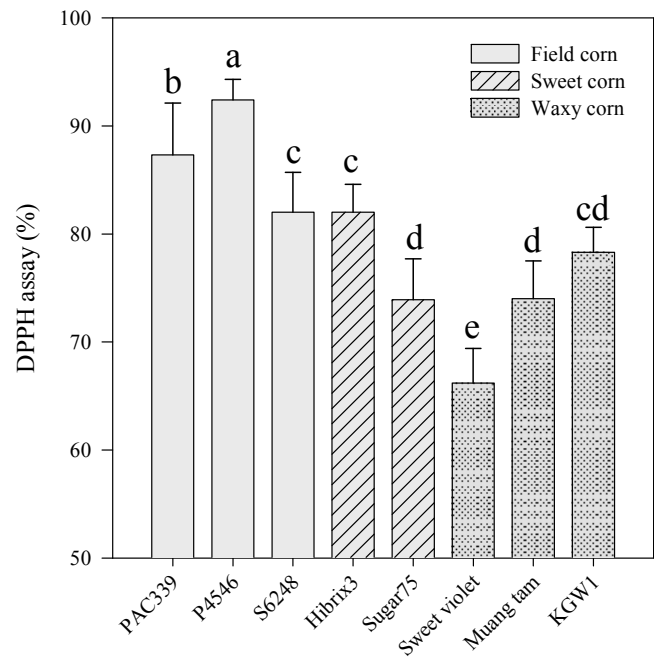

Figure 6. Mean DPPH radical scavenging capacity in the tassels of eight corn varieties.

The antioxidant capacity determined by the TEAC method ranged from 54.1 to $61.2 \mu \mathrm{mol}$ TE/g DW (Figure 5b). P4546 had the highest TEAC values at the 1st day of pollen shed and $50 \%$ and $75 \%$ of pollen shed stages (79.1, 79.3, and $76.2 \mu \mathrm{mol} \mathrm{TE} / \mathrm{g}$ DW sample, respectively), KGW1 also had the highest TEAC values at the 1st day of pollen shed and 50\% of pollen shed stages (81.3 and $74.9 \mu \mathrm{mol}$ TE/g DW sample), and PAC339 had the highest values at 50\% of pollen shed (77.2 $\mu \mathrm{mol} \mathrm{TE} / \mathrm{g}$ DW sample) (Table 6). However, the antioxidant levels obtained from this research were lower than those obtained in purple corn kernel [35] and fresh corn pollen by TEAC assay in previous studies [9].

The results indicated that the greatest antioxidant activity in the tassels exists in pollen. According to Aličić, et al. [40], the major components of pollen are carbohydrates, crude fibers, proteins, and lipids, and the minor components include minerals, trace elements, vitamins, carotenoids, phenolic compounds, flavonoids, sterols, terpenes, and amino acids. Although a number of these components have antioxidant activity, phenolics contribute the most to antioxidant activity in pollen [9]. Thus, the late tassel developmental stage with the lowest level of pollen grains had the lowest pollen fresh weigth and pollen dry weight, resulting in a reduction in the antioxidant activity. 
Table 6. Means for the TEAC radical scavenging capacity in the tassels of eight corn varieties evaluated at four tassel development stages.

\begin{tabular}{|c|c|c|c|c|c|}
\hline \multirow[b]{2}{*}{ Varieties } & \multicolumn{5}{|c|}{ TEAC ( $\mu \mathrm{mol} \mathrm{TE/g} \mathrm{DW} \mathrm{Sample)}$} \\
\hline & VT Tassel & $\begin{array}{l}\text { 1st Day of } \\
\text { Pollen Shed }\end{array}$ & $\begin{array}{c}50 \% \text { of } \\
\text { Pollen Shed }\end{array}$ & $\begin{array}{c}75 \% \text { of } \\
\text { Pollen Shed }\end{array}$ & Mean \\
\hline \multicolumn{6}{|l|}{ Field corn } \\
\hline PAC339 & $61.2 \pm 9.9 \mathrm{~d}-\mathrm{g}$ & $62.3 \pm 10.5 \mathrm{~d}-\mathrm{f}$ & $77.2 \pm 3.9 \mathrm{a}-\mathrm{c}$ & $59.0 \pm 7.3 \mathrm{e}-\mathrm{h}$ & $64.9 \pm 6.3 \mathrm{C}$ \\
\hline P4546 & $69.8 \pm 11.9 \mathrm{~b}-\mathrm{d}$ & $79.1 \pm 10.3 \mathrm{ab}$ & $79.3 \pm 1.8 \mathrm{ab}$ & $76.2 \pm 4.7 \mathrm{a}-\mathrm{c}$ & $76.1 \pm 6.0 \mathrm{~A}$ \\
\hline S6248 & $64.9 \pm 8.3 \mathrm{~d}-\mathrm{f}$ & $68.6 \pm 3.9 c-e$ & $57.4 \pm 4.7 \mathrm{f}-\mathrm{i}$ & $58.7 \pm 3.9 \mathrm{f}-\mathrm{h}$ & $62.4 \pm 3.8 \mathrm{C}$ \\
\hline Mean & 65.3 & 70.0 & 71.3 & 64.6 & 67.8 \\
\hline \multicolumn{6}{|l|}{ Sweet corn } \\
\hline Hibrix3 & $70.3 \pm 0.3 \mathrm{~b}-\mathrm{d}$ & $68.8 \pm 1.2 \mathrm{~cd}$ & $55.5 \pm 9.3 \mathrm{f}-\mathrm{i}$ & $59.1 \pm 10.8 \mathrm{e}-\mathrm{g}$ & $63.4 \pm 5.2 \mathrm{C}$ \\
\hline Sugar75 & $52.3 \pm 3.6 \mathrm{~g}-\mathrm{j}$ & $44.2 \pm 9.4 \mathrm{jk}$ & $57.2 \pm 7.7 \mathrm{f}-\mathrm{i}$ & $49.3 \pm 0.3 \mathrm{~h}-\mathrm{j}$ & $50.8 \pm 1.8 \mathrm{D}$ \\
\hline Mean & 61.3 & 56.5 & 56.3 & 54.2 & 57.1 \\
\hline \multicolumn{6}{|l|}{ Waxy corn } \\
\hline Sweet violet & $47.9 \pm 10.0 \mathrm{ij}$ & $36.8 \pm 10.6 \mathrm{k}-\mathrm{m}$ & $44.3 \pm 0.1 \mathrm{jk}$ & $34.3 \pm 5.4 \mathrm{~lm}$ & $40.8 \pm 6.4 \mathrm{E}$ \\
\hline Muang tam & $37.4 \pm 10.6 \mathrm{k}-\mathrm{m}$ & $42.8 \pm 9.3 \mathrm{j}-1$ & $43.6 \pm 2.2 j-1$ & $33.4 \pm 4.4 \mathrm{~m}$ & $39.3 \pm 6.4 \mathrm{E}$ \\
\hline KGW1 & $63.0 \pm 7.2 \mathrm{~d}-\mathrm{f}$ & $81.3 \pm 7.6 \mathrm{a}$ & $74.9 \pm 9.1 \mathrm{a}-\mathrm{c}$ & $62.5 \pm 11.1 \mathrm{~d}-\mathrm{f}$ & $70.4 \pm 5.8 \mathrm{~B}$ \\
\hline Mean & 49.4 & 53.6 & 54.3 & 43.4 & 50.2 \\
\hline
\end{tabular}

TEAC: Trolox equivalent antioxidant capacity, TE: Trolox equivalents, DW: dry weight. Data are expressed as the mean \pm SD of three replicates. Means with the same letter(s) in the same column are not significantly different $(p \leq 0.05)$, as determined by LSD.

In general, natural bioactive compounds play important roles in improving the health of various populations. Fruits and vegetables are well-known souces of these compounds. However, some agricultural byproducts that are normally considered as waste have high contents of phytochemicals that are potentially useful for industrial applications. Corn tassel with pollen is a byproduct from the corn production field, and it might be a new source for agro-industry utilizations.

In comparison with vegetables and fruits that have higher contents of phytochemicals than corn byproducts, corn byproducts should be more practical due to their lower cost. However, the byproducts from field corn production are more practical for use as a raw material than the byproducts from hybrid seed production, as the amount of the byproduct is sufficient for the commercial scale, and it is important to verify the appropriate time for harvest. In this study, the most appropriate times for tassel harvest were shown to be from the 1 st day to $50 \%$ of pollen shed. Although corn tassel has a lower bioactive content than some plants, such as some fruits and vegetables, corn tassel is still interesting because corn is produced on a large scale and a large amount of corn tassel is available.

Harvesting 50\% of tassel and leaving the rest of the tassel in the field does not affect seed setting in corn grain production. Thus, tassel from the grain production field has potential for use as a raw material for the production of several value-added products. Corn tassel can generate additional income to corn growers and can also help reduce production costs. As corn waste is reduced, corn production should be more effective and sustainable. However, further research should focus on the environmental effects, harvest methods, and the effects of post-harvest on bioactive properties.

\section{Conclusions}

P4546 field corn tassels showed the highest phenolic content and level of antioxidant activity. However, the highest phenolic yield was found in the Hibrix 3 sweet corn variety. This variety has larger tassels that produce a larger amount of pollen. KGW1 purple waxy corn was the best variety for anthocyanin and carotenoid production in corn tassel. The development stage affected the accumulation of phytochemicals and antioxidant potential in tassel. The suitable time for extracting phytochemicals and antioxidant should be from the 1 st day to $50 \%$ of pollen shed. Corn tassel is a potential source of natural phenolics, anthocyanins, and carotenoids as well as antioxidant activity, 
and it could be used as functional food supplement, and an ingredient in natural pharmaceuticals and cosmetic products.

Author Contributions: Conceptualization, P.D., D.K., K.L. (Kamol Lertrat) and B.S.; Formal analysis, P.D., M.P.S. and B.S.; Methodology, P.D., K.L. (Khomsorn Lomthaisong) and B.S.; Writing-original draft, P.D. and B.S.; Writing-review \& editing, D.K., K.L. (Kamol Lertrat), K.L. (Khomsorn Lomthaisong) and M.P.S.

Funding: This research was funded by The Thailand Research Fund through the Royal Golden Jubilee Ph.D. Program grant number [PHD/0039/2558].

Acknowledgments: The Plant Breeding Research Center for Sustainable Agriculture, Faculty of Agriculture, Khon Kaen University, Thailand is also acknowledged for providing research facilities. Acknowledgement is extended to Khon Kaen University and the Faculty of Agriculture for providing financial support for manuscript preparation activities.

Conflicts of Interest: The authors declare no conflict of interest. The funding sponsers had no role in the design of the study; in the collection, analyses, or interpretation of data; in the writing of the manuscript, and in the decision to publish the results.

\section{References}

1. Sarepoua, E.; Tangwongchai, R.; Suriharn, B.; Lertrat, K. Influence of variety and harvest maturity on phytochemical content in corn silk. Food Chem. 2015, 169, 424-429. [CrossRef] [PubMed]

2. Thapphasaraphong, S.; Rimdusit, T.; Priprem, A.; Puthongking, P. Crops of waxy purple corn: A valuable source of antioxidative phytochemicals. Int. J. Adv. Agric. Environ. Eng. 2016, 3, 73-77.

3. Dong, J.; Cai, L.; Zhu, X.; Huang, X.; Yin, T.; Fang, H.; Ding, Z. Antioxidant activities and phenolic compounds of cornhusk, corncob and stigma maydis. J. Braz. Chem. Soc. 2014, 25, 1956-1964. [CrossRef]

4. Li, C.Y.; Kim, H.W.; Won, S.R.; Min, H.K.; Park, K.J.; Park, J.Y.; Ahn, M.S.; Rhee, H.I. Corn husk as a potential source of anthocyanins. J. Agric. Food Chem. 2008, 56, 11413-11416. [CrossRef] [PubMed]

5. Han, X.; Shen, T.; Lou, H. Dietary polyphenols and their biological significance. Int. J. Mol. Sci. 2007, 8, 950-988. [CrossRef]

6. Kiesselbach, T.A. The Structure and Reproduction of Corn; Niversity of Nebraska Press: Lincoln, NE, USA, 1949; p. 101.

7. Aylor, D.E. Survival of maize (Zea mays) pollen exposed in the atmosphere. Agric. Forest Meteorol. 2004, 123, 125-133. [CrossRef]

8. MacRobert, J.F.; Setimela, P.S.; Gethi, J.; Worku, M. Maize Hybrid Seed Production Manual; CIMMYT: Mexico, Mexico, 2014; p. 26.

9. Žilic', S.; Vančetovic', J.; Jankovic', M.; Maksimovic', V. Chemical composition, bioactive compounds, antioxidant capacity and stability of floral maize (Zea mays L.) pollen. J. Funct. Foods 2014, 10, 65-74. [CrossRef]

10. Khider, M.; Elbanna, K.; Mahmoud, A.; Owayss, A.A. Egyptian honeybee pollen as antimicrobial, antioxidant agents, and dietary food supplements. Food Sci. Biotechnol. 2013, 22, 1461-1469. [CrossRef]

11. Mohsen, S.M.; Ammar, A.S.M. Total phenolic contents and antioxidant activity of corn tassel extracts. Food Chem. 2009, 112, 595-598. [CrossRef]

12. Wang, L.; Yu, Y.; Fang, M.; Zhan, C.; Pan, H.; Wu, Y.; Gong, Z. Antioxidant and antigenotoxic activity of bioactive extracts from corn tassel. J. Huazhong Univ. Sci. Technol. Med. Sci. 2014, 34, 131-136. [CrossRef] [PubMed]

13. Wille, J.J.; Berhow, M.A. Bioactives derived from ripe corn tassels: A possible new natural skin whitener, 4-hydroxy-1-oxindole-3-acetic acid. Curr. Bioact. Compd. 2011, 7, 126-134. [CrossRef]

14. Schmitzer, V.; Veberic, R.; Osterc, G.; Stampar, F. Changes in the phenolic concentration during flower development of rose 'KORcrisett'. J. Am. Soc. Hortic. Sci. 2009, 134, 491-496.

15. Joshi, R.; Poonam; Gulati, A. Biochemical attributes of tea flowers (Camellia sinensis) at different developmental stages in the Kangra region of India. Sci. Hortic. 2011, 130, 266-274. [CrossRef] 
16. Salem, N.; Msaada, K.; Hamdaoui, G.; Limam, F.; Marzouk, B. Variation in phenolic composition and antioxidant activity during flower development of safflower (Carthamus tinctorius L.). J. Agric. Food Chem. 2011, 59, 4455-4463. [CrossRef] [PubMed]

17. Ammar, I.; Ennouri, M.; Khemakhem, B.; Yangui, T.; Attia, H. Variation in chemical composition and biological activities of two species of Opuntia flowers at four stages of flowering. Ind. Crops Prod. 2012, 37, 34-40. [CrossRef]

18. Yang, Z.; Fan, G.; Gu, Z.; Han, Y.; Chen, Z. Optimization extraction of anthocyanins from purple corn (Zea mays L.) cob using tristimulus colorimetry. Eur. Food Res. Technol. 2008, 227, 409-415. [CrossRef]

19. Alfieri, M.; Hidalgo, A.; Berardo, N.; Redaelli, R. Carotenoid composition and heterotic effect in selected Italian maize germplasm. J. Cereal Sci. 2014, 59, 181-188. [CrossRef]

20. Singleton, V.L.; Rossi, J.A. Colorimetry of total phenolics with phosphomolybdic-phosphotungistic acid reagents. Am. J. Enol. Vitic. 1965, 16, 144-158.

21. Hu, Q.-P.; Xu, J.-G. Profiles of carotenoids, anthocyanins, phenolics, and antioxidant activity of selected color waxy corn grains during maturation. J. Agric. Food Chem. 2011, 59, 2026-2033. [CrossRef] [PubMed]

22. Giusti, M.M.; Wrolstad, R.E. Characterization and measurement of anthocyanins by UV-visible spectroscopy. In Current Protocols in Food Analytical Chemistry; Wrolstad, R.E., Acree, T.E., An, H., Decker, E.A., Penner, M.A., Reid, D.S., Schwartz, S.J., Shoemaker, C.F., Sporns, P., Eds.; John Wiley \& Sons Inc.: New York, NY, USA, 2001; pp. F1.2.1-F1.2.13.

23. Rivera, S.; Canera, R. Influence of sample processing on the analysis of carotenoids in maize. Molecules 2012, 17, 11255-11268. [CrossRef] [PubMed]

24. Brand-Williams, W.; Cuvelier, M.E.; Berset, C. Use of a free radical method to evaluate antioxidant activity. Food Sci. Technol. 1995, 28, 25-30. [CrossRef]

25. Re, R.; Pellegrini, N.; Proteggente, A.; Pannala, A.; Yang, M.; Rice-Evans, C. Antioxidant activity applying an improved ABTS radical cation decolorization assay. Free Radic. Biol. Med. 1999, 26, 1231-1237. [CrossRef]

26. Gomaz, K.A.; Gomez, A.A. Statistical Procedures for Agricultural Research, 2nd ed.; John Wiley and Sons: Singapore, 1984; p. 680.

27. Harakotr, B.; Suriharn, B.; Scott, M.P.; Lertrat, K. Genotypic variability in anthocyanins, total phenolics, and antioxidant activity among diverse waxy corngermplasm. Euphytica 2014, 203, 237-248. [CrossRef]

28. Tanaka, Y.; Sasak, N.; Ohmiya, A. Biosynthesis of plant pigments: Anthocyanins, betalains and carotenoids. Plant J. 2008, 54, 733-749. [CrossRef] [PubMed]

29. Fonseca, A.; Westgate, M.; Grass, L.; Dornbos, D. Tassel morphology as an indicator of potential pollen production in maize. Crop Manage. 2003. [CrossRef]

30. Ricci, B.; Monod, H.; Guérin, D.; Messéan, A.; Maton, C.; Balique, B.; Angevin, F. Predicting maize pollen production using tassel morphological characteristics. Field Crops Res. 2012, 136, 107-115. [CrossRef]

31. Xu, G.; Wang, X.; Huang, C.; Xu, D.; Li, D.; Tian, J.; Chen, Q.; Wang, C.; Liang, Y.; Wu, Y.; et al. Complex genetic architecture underlies maize tassel domestication. New Phytol. 2017, 214, 852-864. [CrossRef] [PubMed]

32. Lattanzio, V. Phenolic compounds: Introduction, In Natural Products; Ramawat, K.G., Mérillon, J.M., Eds.; Springer-Verlag: Heidelber, Germany, 2013; pp. 1543-1580.

33. Cheynier, V.; Comte, G.; Davies, K.M.; Lattanzio, V.; Martens, S. Plant phenolics: Recent advances on their biosynthesis, genetics, and ecophysiology. Plant Physiol. Biochem. 2013, 72, 1-20. [CrossRef] [PubMed]

34. Shetty, K. Role of proline-linked pentose phosphate pathway in biosynthesis of plant phenolics for functional food and environmental applications: A review. Process Biochem. 2004, 39, 789-804. [CrossRef]

35. Harakotr, B.; Suriharn, B.; Tangwongchai, R.; Scott, M.P.; Lertrat, K. Anthocyanins and antioxidant activity in coloured waxy corn at different maturation stages. J. Func.Foods. 2014, 9, 109-118. [CrossRef]

36. Bakó, E.; Deli, J.; Tóth, G. HPLC study on the carotenoid composition of Calendula products. J. Biochem. Biophys. Methods 2002, 53, 241-250. [CrossRef]

37. Bogdanov, S. Pollen: Nutrition, Functional Properties, Health: A review. Available online: http://www.beehexagon.net/files/file/fileE/Health/PollenBook2Review.pdf (accessed on 19 May 2017).

38. Menkir, A.; Liu, W.; White, W.S.; Maziya-Dixon, B.; Rocheford, T. Carotenoid diversity in tropical-adapted yellow maize inbred lines. Food Chem. 2008, 109, 521-529. [CrossRef] 
39. Hwang, T.; Ndolo, V.U.; Katundu, M.; Nyirenda, B.; Bezner-Kerr, R.; Arntfield, S.; Beta, T. Provitamin A potential of landrace orange maize variety (Zea mays L.) grown in different geographical locations of central Malawi. Food Chem. 2016, 196, 1315-1324. [CrossRef] [PubMed]

40. Aličić, D.; Šubarić, D.; Jašić, M.; Pašalić, H.; Ačkar, Đ. Antioxidant Properties of Pollen. Available online: http:/ / www.hrcak.srce.hr/file/186516 (accessed on 16 February 2018). 